\title{
RANCANG BANGUN MUSIK ANGKLUNG MODEL SATB, DASAR ARANSEMEN MODEL ORCHESTRA
}

\author{
Oleh: \\ Susilo Pradoko dan Wien Pudji Priyanto \\ Jurusan Pendidikan Seni Musik, FBS, Universitas Negeri Yogyakarta \\ susilopradoko@uny.ac.id
}

\begin{abstract}
Abstrak
Penciptaan karya seni angklung model SATB-SP ini merupakan karya seni guna mengembangkan permainan dan teknik bermnain angklung sebagai warisan budaya tak benda UNESCO. Karya ini memiliki tujuan memadukan teori ilmu harmoni 4 suara seta sistem tuts piano untuk bermain angklung sehingga hanya dengan 4 orang pemain sudah mampu menghasilkan bunyi/suara harmoni sekualitas permainan orchestra. Metode dalam penciptaan karya seni angklung SATB-SP ini dengan metode penelitian dan pengembangan (Research and development) dengan modifikasi pada bagian revisi penciptaan karya seni dan pementasan serta produksi masal diganti dengan publikasi masal. Hasil penciptaan karya seni angklung SATB-SP adalah sebagai beriokut: (1) Semua aransemen paduan SATB dapat dimainkan dengan angklung SATB-SP, (2) Aransemen paduan suata sejenis, paduan suara anak dapat dimainkan dengan angklung SATB-SP, (3) Cara memainkannya mudah, satu orang bisa memainkan 3 nada atau akor, (4) Angklung SATB-SP ini dapat digabungkan dengan Symphonic Orchestra, (5) Angklung SATB-SP juga dapat digabungkan dengan musik Band dan musik tradisional lainnya seperti Gejog Lesung, (6) Alat musik ini dapat diasambelkan dengan alat-alat musik tradisional seperti: Kendang suling dsb (7) Dua orang pemain mampu membuat harmoni musik dua s/d enam nada anggota anggota akor, (8) Pementasan musik angklung tidak satu paket kerangka dan (9) alat musik ini dapat digunakan untuk melatif kreativitas kejeniusan melodi dan harmoni.
\end{abstract}

Kata kunci : Rancang bangun, Musik angklung, Model SATB-SP 


\title{
THE DESIGN OF ANGKLUNG MUSICAL INSTRUMENT WITH SATB MODEL AND ORCHESTRA BASIC ARRANGEMENT MODEL
}

\begin{abstract}
The creation of Angklung music instrument using STAB model is a kind of artwork having the effort of developing the play and the playing technique of angklung as one intangible cultural heritage listed by UNESCO. This design is to combine the theories of the harmony of four chorus and keyboard system in piano to play angklung so that only four players can perform sound harmony with the quality of an orchestra. The method used in the creation of angklung SATB-SP is research and development by modifying the parts of revision in the art creation and performance and also mass production, which are changed into mass publication. The results of the creation of angklung SATB-SP are as follows. (1) All the arrangement of SATB can be played with angklung. (2) The arrangement for children's choir can be played with angklung SATBSP. (3) It is easy to play: one player can even play three tones. (4) Angklung SATB-SP can be combined with Symphonic Orchestra, (5) Angklung SATB-SP can also be combined with band music as well as other traditional kinds of music such as Gejog Lesung. (6) This music instrument can create ensemble together with traditional music instruments such as kendang, suling etc. (7) Two players can make a musical harmony between 2 to 6 musical notes. (8) The performance of Angklung is not one frame package. (9) This music instrument can be used to practice in improving the creativity and intelligence in melody and harmony.
\end{abstract}

Keywords : design, Angklung, SATB-SP model 


\section{PENDAHULUAN}

\section{Latar Belakang Pengembangan Instrumen Angklung}

Angklung telah ditetapkan sebagai warisan budaya tak benda (Intangible, Cultural Heritage of Humanity) oleh Organisasi pendidikan, Ilmu Pengetahuan, dan Kebudayaan (UNESCO) Peserikatan Bangsa-Bangsa (PBB) pada bulan November 2010. Sementara itu Duta Besar Indonesia untuk UNESCO menyatakan bahwa dalam waktu empat tahun bila Indonesia tidak bisa melestarikan serta mengembangkannya maka pengakuan warisan budaya tek benda tersebut bisa dicabut. (Kampas, 20 Januari 2011). Perguruan Tinggi memiliki tugas pengembangan Ilmu khususnya Angklung ini, sebab selama ini angklung belum banyak dikaji secara akademik melalui penelitian namun hanya dilestarikan dan dikembangkan melalui para pengrajin Angklung. Pengrajin angklung yang masih rutin berproduksi di Indonesia ini hanya dua kelompok yaitu Serambu Sumitro di Yogyakarta dan Saung Angklung Ujo. Pengembangan dalam bidang Ilmu dan teknologi Angklung tidak cukup hanya diserahkan pada dua sentra pengrajin tersebut karena keduanya tidak memiliki tradisi metodologi penelitian ilmiah. Andil Perguruan Tinggi dalam pengembangan angklung sangat perlu agar kurun 3 tahun lagi setelah diamati PBB tidak dijatuhkan sangsi pencabutan warisan budaya tak benda tersebut. Jurusan Seni Musik FBS UNY memiliki potensi guna pengembangan akademik musik Angklung, selain Universitas Pendidikan Indonesia (UPI) Bandung, dengan demikian pelopor pengembangan metodologis angklung diharapkan muncul dari UNY dan UPI.

Indonesia miskin tenaga ahli yang memiliki kemampuan melakukan metode penelitian ilmiah tentang etnomusikologi angklung. Hal itu dikhawatirkan akan mempengaruhi pengembangan angklung dan statusnya sebagai warisan budaya tak benda dari Indonesia. Husein Hendriyana, Kepala Bidang Penelitian dan Pengabdian Masyarakat STSI Bandung. menyatakan sebagai berikut: “ Para pakar atau orang yang paham tentang angklung mungkin banyak. Tetapi yang mengerti metodologi penelitian ilmiah yang terstruktur saya rasa belum ada. Hal itu sangat ironis mengingat Indonesia merupakan negara asal angklung". (Kompas, 9 Februari 2011: 12) .Universitas Negeri Yogyakarta dapat merupakan salah satu pusat pengembangan akademik dalam bidang 
musik angklung karena secara nyata memang masih langka pakar metodologi ilmiah tentang angklung.

Angklung telah ditetapkan pula sebagai alat pendidikan musik sejak tanggal 23 Agustus 1968. melalui Keputusan Menteri Kebudayaan No.082/1968 tentang penetapan angklung sebagai alat pendidikan musik namun sampai saat ini pengembangan maupun penerapannya di sekolah-sekolah masih sangat minim. Perhatian dunia perguruan tinggi memang masih sangat kurang hal ini disebabkan pula masih sangat jarang Perguruan Tinggi yang memberikan materi mata kuliah angklung sehingga aspek metodologis dan praksisnya dalam pertunjukan musik juga sulit berkembang.Selain itu peralatan angklung yang ditata memanjang dengan bentuk yang relative besar-besar untuk satu nada, sehingga memakan banyak tempat memerlukan kesulitan tersendiri dalam penyimpanan angklung di ruangan/kelas. Guru musik yang memiliki kemampuan teoritis musik angklung maupun metodologis dalam menyampaikan pembelajaran musik hingga pementasan juga sangat sedikit, karena pencantuman angklung sebagai materi mata kuliah baru dilakukan oleh UPI dan UNY, sebagai LPTK pendidik guru di sekolahsekolah. Pembelajaran angklung dengan menggabungkan orchestra telah dirintis penulis sejak tahun 1996 dalam mara kuliah Musik Nusantara dan mata kuliah Etnomusikologi. Pengembangan angklung sangat minim di Indonesia ini baik dari sisi metodologi musikal, pembelajaran maupun pengembangan peralatan musik angklung untuk itulah maka Seni Musik FBS UNY terbeban untuk pengembangan musik angklung yang telah diakui UNESCO sebagai Intangible, Cultural Heritage of Humanity tersebut/

\section{Angklung Satu Nada Satu Pemain.}

Angklung yang diajarkan selama ini masih berpola pada permainan satu nada dibunyikan oleh seorang pemain. Permainan model ini membutuhkan banyak orang untuk menghasilkan bunyi harmoni yang terpadu. Permainan model angklung seperti ini setidaknya memerlukan sekitar 25 orang pemain agar suaranya menjadi harmonis berdasarkan susunan nada-nada dan pemilihan teknik akor yang digunakan.

\section{Angklung Akompanyemen}

Angklung akompanyemen digunakan untuk mengiringi melodi yang dihasilkan dari permainan model angklung satu-satu nada yang telah diuraikan sebelumnya. Angklung ini merupakan angklung akor, dalam satu angklung ada 3 tabung yang 
merupakan bunyi-bunyi akor nada-nadanya, sehingga mampu untuk mengiringi menjadi lebih indah, salah satu diantaranya misalnya angklung akompanyemen akor $\mathrm{C}$.

\section{Angklung Model SATB}

Angklung model SATB ini terinspirasi dari materi Teori Musik. Dalam Teori Musik khususnya pokok bahasan harmoni ada model harmoni empat suara manusia yaitu suara Sopran, Alto, Tenor dan Bas atau sering disebut sebagai (Four Part Harmony Model). Model harmoni 4 suara tersebut merupakan paduan nada-nada yang terdiri dari unsur-unsur akor. Akor adalah pengabungan dari tiga nada atau lebih yang menghasilkan suara indah dan terpadu. Salah satu contoh akor C, terdiri dari nada-nada do, mi, sol atau nada c, e dan g. Dalam format SATB ada 4 buah nada maka dari 3 akor tersebut satu nada dibuat dobel sehingga menjadi empat nada misalnya nada yang didobel adalah c, sehingga nada-nada yang timbul adalah suara c, e, g,c atau disolmisasikan menjadi do, mi, sol, do. Model harmoni 4 suara ini pula yang menjadi dasar dalam membuat aransemen orchestra.

Dalam harmoni 4 suara terdapat wilayah Sopran, Alto, Tenor dan Bas yaitu wilayah kemampuan manusia untuk menyanyikan nada-nada. Wilayah Sopran memiliki jangkauan nada antara d1 sampai dengan nada f2, wilayah Alto memiliki jangkauan nada dari a sampai dengan nada c2, wilayah Tenor berjangkauan nada d hingga f1 dan wilayah Bas nada F hingga c1. (lihat Benward, 1985: 308). Jangkauan nada-nada wilayah suara manusia itulah yang memungkinkan suara Sopran, Alto, Tenor dan Bas menyanyikan garis melodi sesuai dengan pembuat aransemen lagu. Model seperti inilah yang membuat penyanyi Sopran, Alto, Tenor dan Bas dapat menyanyikan secara bersama dengan menghasilkan paduan yang harmonis antar 4 suara tersebut. Dasar pemikiran inilah yang akan dipakai dalam membuat Model Angklung SATB sehingga dengan pemain sebanyak 4 orang saja dapat menampilkan perpaduan yang harmonis untuk menyajikan lagu-lagu karena di dalam 4 orang pemain angklung tersebut, sudah ada melodi Sopran, suara iringan tengah (Alto dan Tenor) serta suara-suara Bas yang dilakukan oleh pemain angklung Bas. Bila gagasan rancang bangun ini diwujudkan maka permainan angklung tidak memerlukan banyak pemain (sekitar 20 orang lebih) seperti sering dilakukan saat ini di sekolah-sekolah, kampus maupun di kelompok pecinta 
angklung namun cukup 4 orang saja sudah mewakili suara melodi, iringan dan bas yang menyatu.

\section{PEMBAHASAN}

\section{Rancangan Produk Seni Angklung SATB.}

Model angklung SATB dibuat 4 set angklung dengan 4 wilayah suara manusia. Satu set angklung merupakan angklung Sopran dengan wilayah suara nada-nada dari d1 hingga f2. Wilayah Sopran bawah diperluas sedikit dengan asumsi ada nada-nada melodi yang dimulai dari nada a sehingga suara Angklung Sopran mampu memainkan melodi sendiri secara utuh. Selangkapnya lihat gambar berikut ini:

\section{Angklung Sopran:}
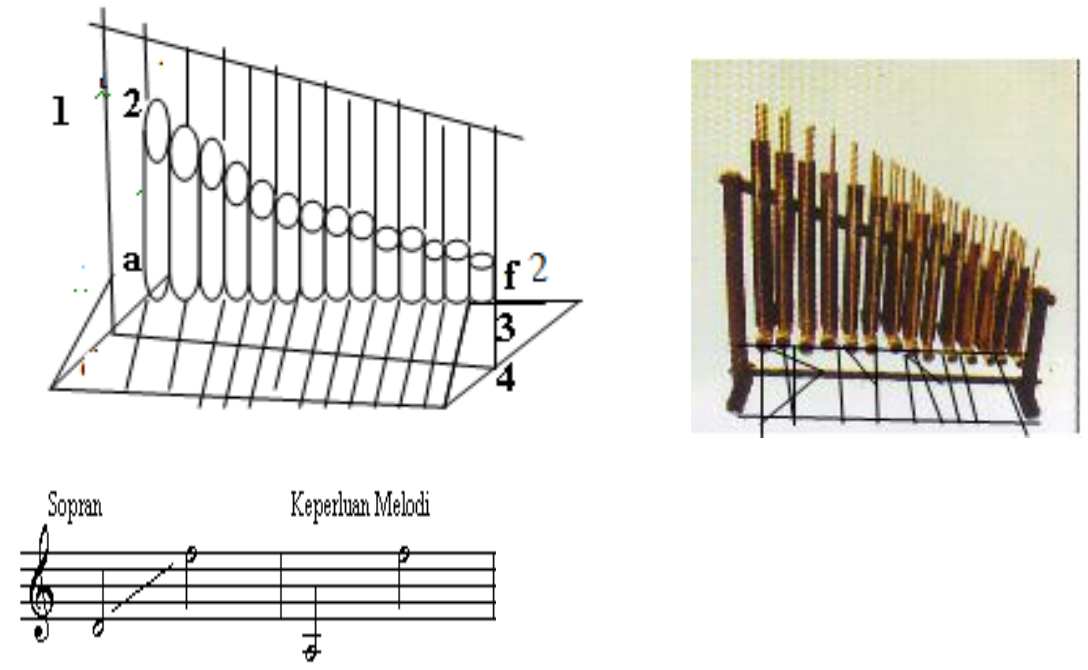

\section{Keterangan:}

1. Kerangka Angklung

2. Tabung-tabung Angklung Nada-nada Wilayah Sopran:

Terdiri dari nada-nada dari a s/d f2 yaitu nada-nada: a, ais, b, c1, cis1, d1,dis1,e1,f1, fis1, g1, gis1,a, ais1, b1, c2, cis2, d2, dis2, e2, f2. Terdiri dari 21 tabung nada dan masing-masing nada ada dua tabung melodi agar ada penguat suara nada pokok; sehingga ada 42 tabung nada untuk Angklung Sopran.

3. Pantulan karet kanan.

4. Pantulan Karet kiri.

$\mathrm{a}=$ tabung pertama nada $\mathrm{a} ; \mathrm{f} 2=$ tabung terakhir nada $\mathrm{f} 2$. 


\section{Angklung Alto :}
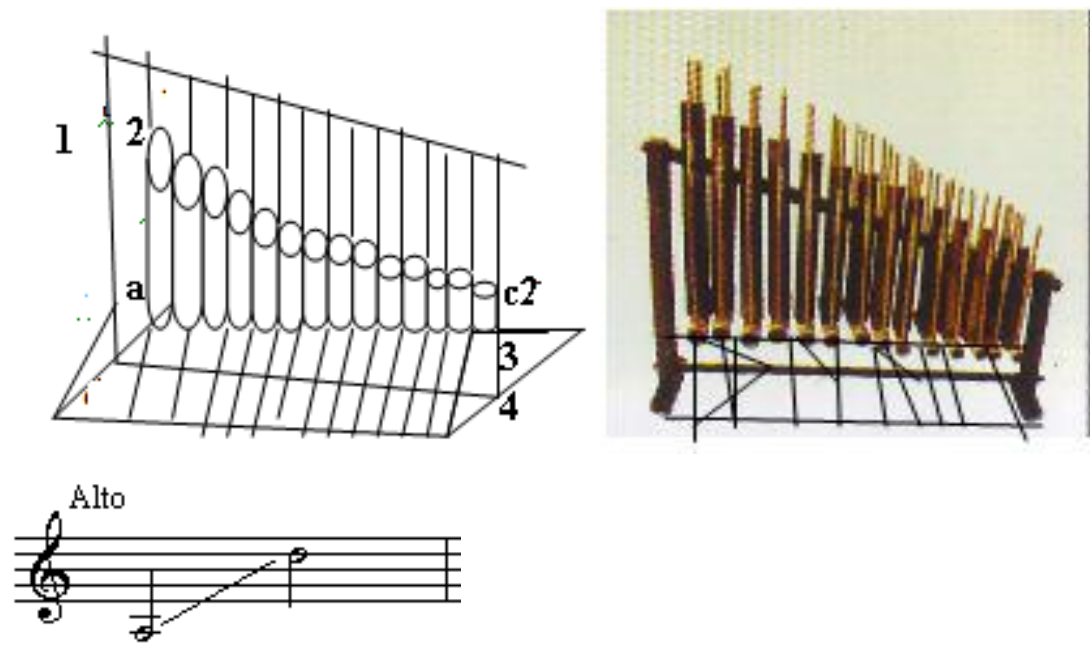

\section{Keterangan:}

1. Kerangka Angklung

2. Tabung-tabung Angklung Nada-nada Wilayah Alto:

Terdiri dari nada-nada dari a s/d c2 yaitu nada-nada: a, ais, b, c1, cis1, d1,dis1,e1,f1, fis1, g1, gis1,a, ais1, b1, c2. Terdiri dari 16 tabung nada dan masing-masing nada ada dua tabung melodi agar ada penguat suara nada pokok; sehingga ada 32 tabung nada untuk AngklungAlto.

3. Pantulan karet kanan.

4. Pantulan Karet kiri.

$\mathrm{a}=$ tabung pertama nada $\mathrm{a} ; \mathrm{c} 2=$ tabung terakhir nada $\mathrm{c} 2$. 


\section{Angklung Tenor:}
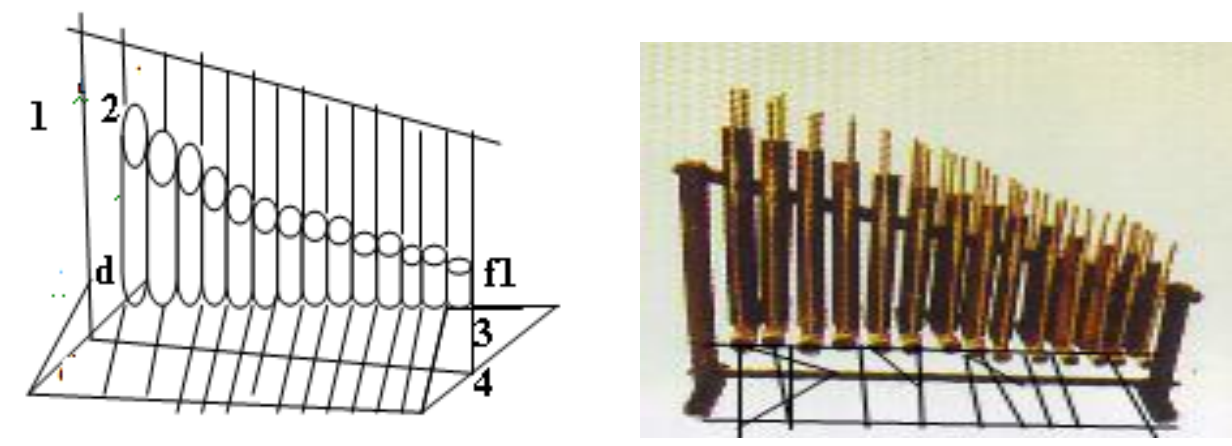

Tenor

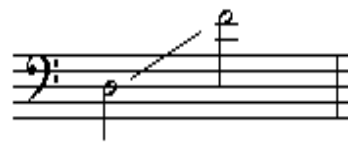

Keterangan:

1. Kerangka Angklung

2. Tabung-tabung Angklung Nada-nada Wilayah Tenor:

Terdiri dari nada-nada dari d s/d f1 yaitu nada-nada: d, dis, e, f, fis, g, gis, a, ais, b, c1, cis1, d1,dis1,e1,f1. Terdiri dari 16 tabung nada dan masing-masing nada ada dua tabung melodi agar ada penguat suara nada pokok; sehingga ada 32 tabung nada untuk AngklungTenor.

3. Pantulan karet kanan.

4. Pantulan Karet kiri.

$\mathrm{d}=$ tabung pertama nada $\mathrm{a} ; \mathrm{f} 1$ = tabung terakhir nada $\mathrm{f} 1$.

\section{Angklung Bas :}
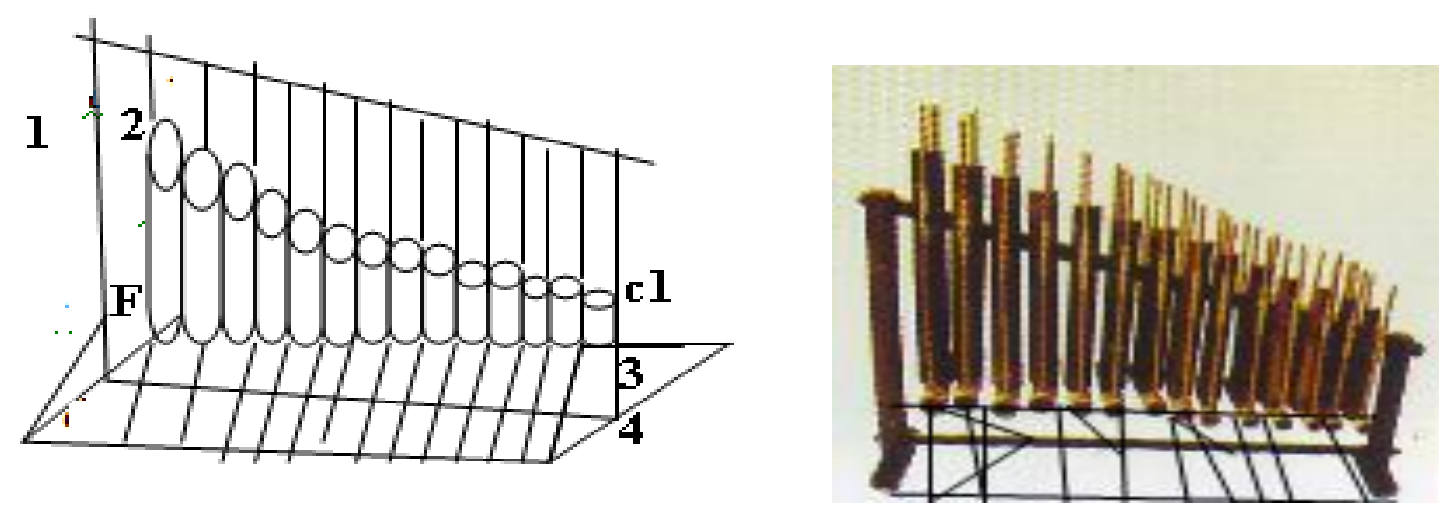


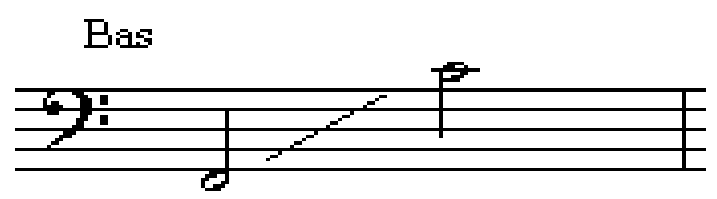

Keterangan:

1. Kerangka Angklung

2. Tabung-tabung Angklung Nada-nada Wilayah Bas:

Terdiri dari nada-nada dari F s/d c1 yaitu nada-nada: F, Fis, G, Gis, A, Ais, B, C, cis, d, dis, e, f, fis, g, gis, a, ais, b, c1. Terdiri dari 20 tabung nada dan masingmasing nada ada dua tabung melodi agar ada penguat suara nada pokok; sehingga ada 40 tabung nada untuk Angklung Bas.

3. Pantulan karet kanan.

4. Pantulan Karet kiri.

$\mathrm{F}=$ tabung pertama nada $\mathrm{F} ; \mathrm{cl}=$ tabung terakhir nada $\mathrm{c} 1$.

Nada-nada kromatik akan diberi tanda hitam pada ujung -ujung atasnya agar dalam memainkan angklung cepat dalam memilih nada-nada yang harus dibunyikan. Berikut contoh penghitaman angklung sesuai nada-nada kromatik sebagaimana dalam piano atau keyboard.

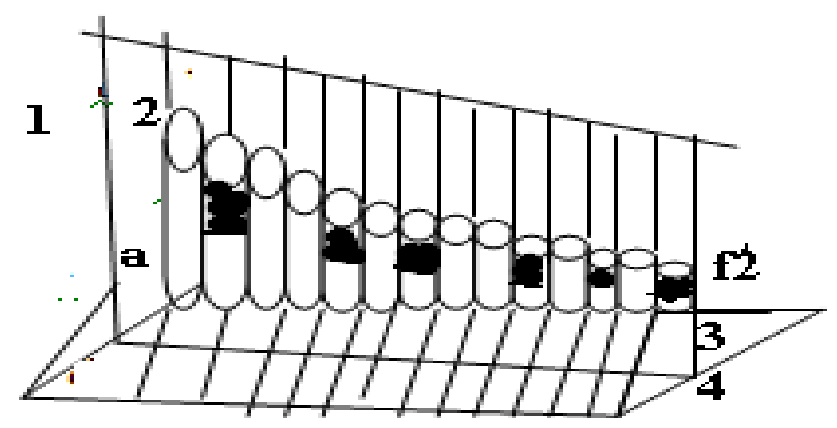

a,ais, b,c1,cis1,d1,dis1,e1,f1,fis1,g1,gis1, a1,ais1, dst...

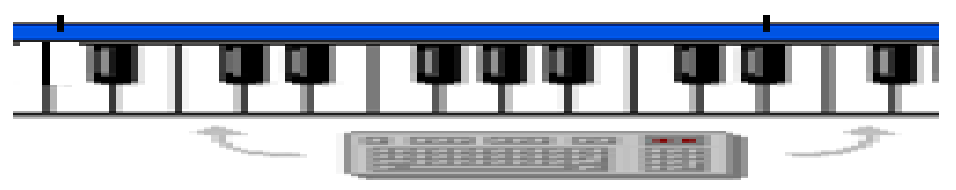

(Sumber gambar dari Keyboard Virtual Encore) 


\section{Tahapan Pembuatan Angklung SATB-SP}

1. Penyediaan Angklung melodi nada - nada kromatik

2. Pembuatan Ancak tempat Angklung Sopran dengan sebanyak 21 Angklung nada a hingga $\mathrm{f} 2$

3. Pembuatan Ancak tempat Angklung Alto dengan sebanyak 16 Angklung nada a hingga c2

4. Pembuatan Ancak tempat Angklung Tenor dengan sebanyak 14 Angklung nada d hingga f2

5. Pembuatan Ancak tempat Angklung Bas dengan sebanyak 18 Angklung nada G hingga c1

6. Pembuatan Pemantul Karet kanan dan kiri yang diikat pada masing-masing angklung melodi

7. Pembuatan mekanik palu - tust model piano guna pemantik dan pemantil nada-nada

8. Pemasangan pemantik palu -tuts piano pada masing-masing nada dalam rangkaian Ancak baik Ancak Sopran, Alto, Tenor dan Bas tepat pada berhadapan dengan tabung-tabung melodi nada masing-masing Ancak.

\section{UJI COBA}

\section{Uji Coba Produk Angklung}

Setelah dibuat tuts-tuts sistem piano untuk seluruh wilayah sopran, alto, tenor dan bas kemudian dirangkai masing-masing tuts dengan bilah panjang dan menyentuh masing-masing nada angklung dengan pemantul karet. Masing-masing perangkat tuts-tuts dicoba kelenturannya dan efek bunyinya baik perangkat sopran, alto, tenor maupun bas.

Setelah produk Angklung Mopdel SATB selesai diproduksi selanjutnya dilakukan uji coba dengan latihan di tempat pembuatan. Angklung Model SATB yang dimainkan oleh 4 orang dengan menampilkan lagu-lagu Daerah dan Lagu Populer. Pementasan akan dimainkan oleh 4 orang, pelaksanaan latihan dan uji coba instrument angklung SATB-SP bertempat di Glondong No.122B Kalasan, tempat pembuatan angklung SATB_SP. Penerapan permaianan alat musik dengan latihan lagu Hymne Guru, Gelang Sipatu Gelang, Aja Dipleroki, You Raise Me Up dan Indonesia Tanah Air Beta. 


\section{Pementasan Musik Angklung SATB-SP}

Pementasan dilakukan di Laboratorium Karawitan Fakultas Bahasa dan Seni UNY pada tanggal 31 Oktober 2014, pukul 08 hingga pukul 10. Pementasan Angklung SATB-SP melibatkan 4 orang pemain. Seorang memainkan angklung sopran, seorang memainkan angklung alto, seorang tenor dan seorang lagi memainkan angklung bas. Masing-masing pemain membaca notasi sesuai nada-nada yang dimainkan dan dapat menambahkan sendiri nada-nada anggota akor sehingga harmoni menjadi lebih penuh. Sebagai contoh akor F yang berisi nada f, a, c, atau lebih mudahnya nada bersuara do, mi, sol bila bermain dalam nada dasar F, dapat ditambah nada-nada lain sehingga menjadi: pemain sopran membunyikan nada mi dan do, pemain angklung alto membunyikan nada sol dan mi, pemain tenor membunyikan do dan sol dan pemain bas membunyikan nada do dan sol atau nada do saja. Cara permainan perangkapan nada dalam satu orang pemain ini membuat rasa harmoni menjadi lebih penuh, 4 pemain angklung mampu memainkan 8 nada-nada anggota suara akor.

Dalam pementasan ini memainkan dua buah lagu. Lagu yang dimainkan adalah lagu Indonesia Pusaka karya Ismail Marzuki dengan aransemen oleh A.M.Susilo Pradoko. Cuplikan lagunya adalah sebagai berikut:

\section{Indonesia Pusaka}

Moderato

Lagu: Ismail Marzuki

Arr.: A.M.Susilo Pradoko
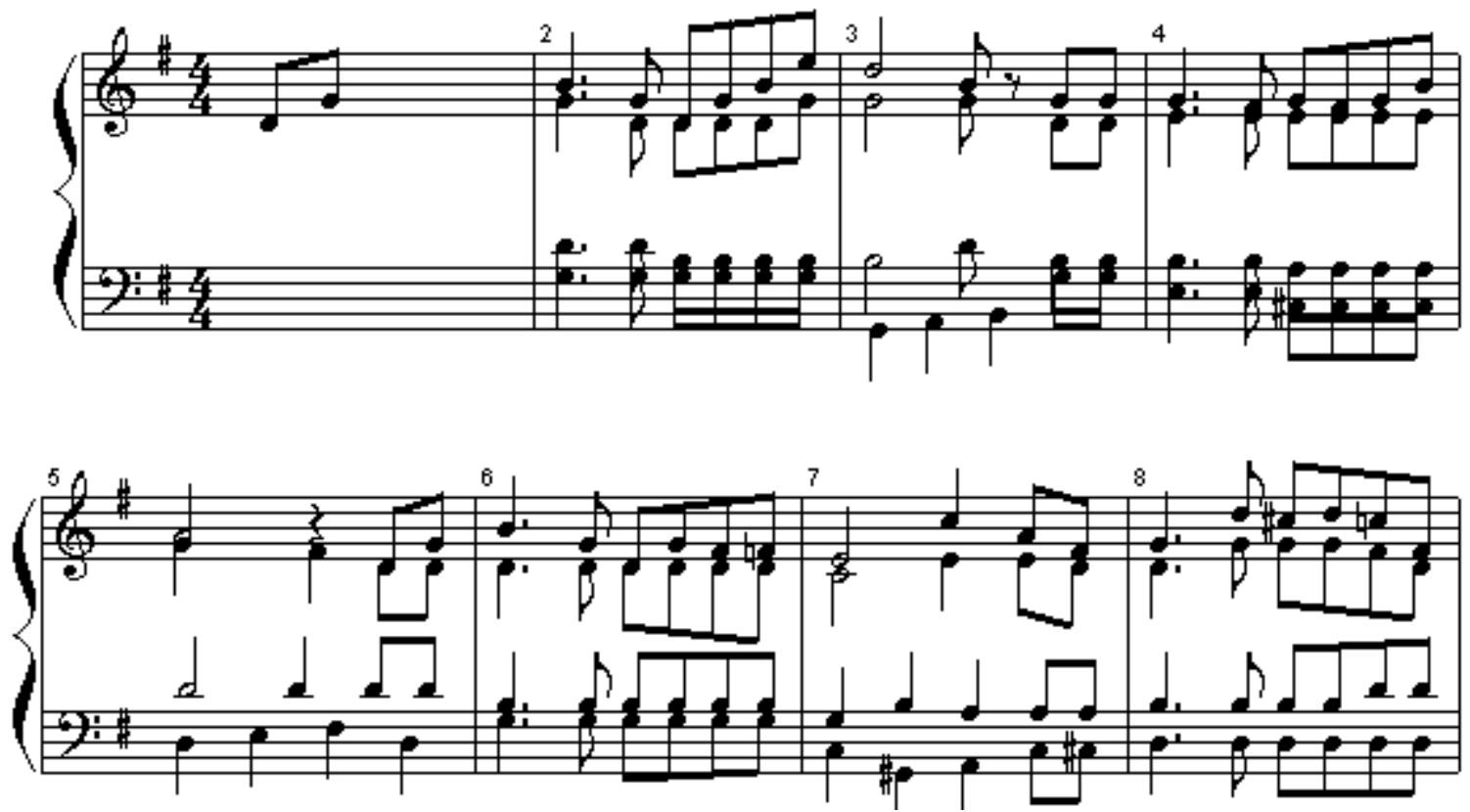
Beberapa akor dibuat balikan sehingga nuansa variasi lebih tepat dengan syair lagu dan harmoni nada-nadanya. Notasi yang bertangkai ke atas pada garis paranada berkunci G dimainn oleh angklung sopran, tangkai ke bawah oleh alto, sedangkan pada garis paranada bertanda kunci $\mathrm{F}$ yang tangkainya ke atas dimainkan oleh angklung tenor dan yang bertangkai ke bawah oleh pemain angklung bas.

Lagu ke dua dalam pementasan ini memainkan lagu You Raise Me Up karya Josh Groban dengan aransemen A.M.Susilo Pradoko. Sudah ada bagian-bagian suara yang harus dimainkan oleh empat orang pemain angklung tersebut, selengkapnya skor notasi lagu kami lampirkan berikut laporan penelitian ini.

\section{HASIL PENCIPTAAN KARYA SENI ANGKLUNG SATB-SP Penerapan Rancang Bangun Musik Angklung Model SATB-SP}

Rancang bangun musik angklung dengan model sopran, alto, tenor dan bas sistem piano ternyata dapat diterapkan dan mampu dimainkan dengan mudah hanya dengan menyentuhkan dengan jari-jari tangan. Pemain dapat memainkan banyak angklung hingga 20 nada sesuai dengan wilaya suara manusia. Sistem konvensional tradisi seorang pemain hanya memainkan satu angklung dengan cara tangan kiri memegang ancak angklung dan tangan kanan menggoyangkan angklung sehingga berbunyi. Pada sistem ini seorang pemain cukup menyentuh dengan jarinya tuts-tust layaknya piano shingga dapat memainkan beberapa angklung sekaligus secara simultan beberapa nada angklung yang berarti dapat memainkan beberapa angklung sekaligus dalam satu waktu, detik dan durasi yang sama.

\section{Hasil Keunggulan Angklung SATB-SP}

1.Semua aransemen paduan SATB dapat dimainkan dengan Angklung SATB-SP.

2.Aransemen paduan suara sejenis, paduan suara anak dapat dimainkan dengan Angklung SATB-SP.

3.Cara memainkannya mudah, satu orang bisa memainkan 3 nada anggota akor.

4.Angklung SATB-SP ini dapat digabungkan dengan Shymphonic Orchestra.

5.Angklung SATB-SP juga dapat digabungkan dengan musik Band.

6.Alat musik ini dapat diansambelkan dengan alat-alat musik tradisi: kendang, suling dsb.

7.Dua orang pemain mampu membuat harmoni musik dua s/d enam nada anggota akor. 
8.Pementasan musik angklung tidak memerlukan belasan/puluhan orang.

9.Peralatan lebih ringkas dalam satu paket kerangka.

10.Alat musik ini dapat digunakan untuk melatih kreativitas kejeniusan melodi dan harmoni.

\section{KESIMPULAN}

Penciptaan karya seni angklung SATB-SP dilakukan dengan proses sebagai berikut: (1) Semua aransemen paduan SATB dapat dimainkan dengan angklung SATBSP, (2) Aransemen paduan suata sejenis, paduan suara anak dapat dimainkan dengan angklung SATB-SP, (3) Cara memainkannya mudah, satu orang bisa memainkan 3 nada atau akor, (4) Angklung SATB-SP ini dapat digabungkan dengan Symphonic Orchestra, (5) Angklung SATB-SP juga dapat digabungkan dengan musik Band dan musik tradisional lainnya seperti Gejog Lesung, (6) Alat musik ini dapat diasambelkan dengan alat-alat musik tradisional seperti: Kendang suling dsb (7) Dua orang pemain mampu membuat harmoni musik dua s/d enam nada anggota anggota akor, (8) Pementasan musik angklung tidak satu paket kerangka dan (9) alat musik ini dapat digunakan untuk melatif kreativitas kejeniusan melodi dan harmoni.

Rancangan tindak lanjut adalah dengan mementaskan di kolaborasikan dengan musik ansambel sekolah, digabungkan dengan musik band dan dipadukan pula dengan full orchestra. Desain selanjutnya akan dibuat menjadi sistem knock down sehingga lebih ringkas untuk di bawa, menjadi portable, dengan demikian maka memudahkan para pemain untuk pentas baik di dalam negeri maupun di luar negeri sebagai ajang pentas budaya. Selanjutnya setelah uji coba akan diusulkan pula sebagai kekayaan hak intelektual (HAKI), Model Angklung SATB Knock Down. 


\section{DAFTAR PUSTAKA}

Benward, Bruce and Jackson, Barbara G. 1985. Practical Beginning Theory. Iowa: C. Brown, Company Publishers.

Frick, Heinz. Ilmu Konstruksi Bangunan Bambu. Pengantar Konstruksi Bambu. Yogyakarta: Penerbit Kanisius.

Glass, Gene V and Kenneth D.Hopkins.1984 Statistical methods in education and psychology. Jersey: Prentice Hall. New

Kawakami, Genichi. 1975. Arranging Popular Music. Tokyo: Yamaha Music Foundation.

Kompas. 2011. "Pengakuan Warisan Budaya Bisa Dicabut" Jakarta: Kompas, tgl 20-12011.

2011. “Tenaga Ahli Angklung Masih Sangat Terbatas” Jakarta: Kompas, tgl 92-2011

Korsakov, Nikolay Rimsky. 1964. Principles of Orchetration. New York: Dover Publication

Pradoko, Susilo. 2008. Cara Mudah Aransemen Lagu Yogyakarta: Diandra Primamitra Media

Sugiyono. 2009. Metode Penelitian Kuantitatif Kualitatif dan $R \& D$. Bandung: Penerbit Alfabeta.

Supriyadi. 2006. "Calung dan Cara Pembuattannya”. dalam Selonding. Yogyakarta: Jurnal Masyarakat Etnomusikologi ISI.

Skinner, Frank. 1980. New Method for Orchestra Scoring. New York: Robin's Music Corporation

Warsono, F.A. 1978. Orkestrasi. Bandung: Raker Komandan Musik TNI AD.

Widyastuti dan Pradoko Susilo. 2010. Diktat Direksi Dasar Lanjut. Yogyakarta: Jurusan Pendidikan Seni Musik FBS UNY

Winisasmita, Moh.Hidayat dan Budiman. 1978. Angklung Petunjuk Praktis. Jakarta: Balai Pustaka. 